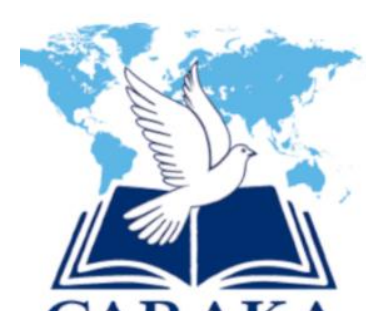

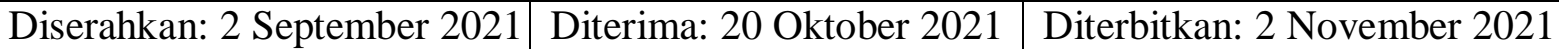

\title{
Gereja sebagai Hamba yang Melayani: Sebuah Perspektif Eklesiologi Transformatif di Era Society 5.0
}

\author{
Bakhoh Jatmiko, Teguh Bowo Sembodo, Albert Yusuf Langke, Sukirdi, Yupiter Hulu
}

\author{
Sekolah Tinggi Theologia Nazarene Indonesia \\ djatcair@sttni.ac.id \\ sembodo70@sttni.ac.id \\ yusuf@sttni.ac.id \\ kirdi@sttni.ac.id \\ piter@sttni.ac.id
}

\begin{abstract}
The era of Society 5.0 presented various opportunities on the one hand and the threat of moral decadence, polarization, inequality, and various forms of social problems that are massively increasing amid society on the other hand. In this kind of wrestling, how should the Church take a role in implementing transformational mandates? The Church is God's gift to the world as His compassion manifestation towards sinners and marginalized groups of exploited and dominated. This research was conducted with a descriptive qualitative method that involves historical and explorative studies of biblical texts and literature research. Historical studies found that the Church took a role from the New Testament, medieval ages to the reform era in carrying out the mandate of spiritual transformation and addressing daily life problems and advocating the fatalist groups among capitalist and paternalist oppression. As a servant, the Church must reflect the existence of Christ as a faithful Servant. The Church must follow, obey the commandments, live the mission, and have the ministry focus as Christ's.
\end{abstract}

Keywords: Ecclesiology; transformative; trinitarian; church; industry revolution; society 5.0

\begin{abstract}
Abstrak
Era peradaban 5.0 menghadirkan banyak peluang di satu sisi dan ancaman akan dekadensi moral, polarisasi, kesenjangan dan berbagai rupa persoalan sosial di tengah-tengah masyarakat di pihak lain. Di dalam pergumulan ini, bagaimanakah gereja harus berperan di dalam mengimplementasikan madat pembaharuan? Gereja adalah anugerah Allah bagi dunia sebagai manifestasi belas kasihan Allah terhadap manusia berdosa dan juga kaum marginal yang mengalami ekspoitasi dan dominasi. Penelitian ini menggunakan metode kualitatif deskriptif yang melibatkan kajian historis dan eksploratif dari teks Alkitab dan berbagai literatur. Kajian historis di dalam penelitian ini menemukan bahwa gereja berperan sejak Perjanjian Baru, abad pertengahan hingga era reformasi bukan hanya melaksanakan mandat pembaharuan spiritual; tetapi juga berperan mengatasi problematisasi kehidupan sehari-hari serta memberikan
\end{abstract}


advokasi bagi kelompok fatalis di tengah opresi para kapitalis dan paternalis. Sebagai hamba yang melayani gereja merefleksikan keberadaan Kristus sebagai Hamba yang setia. Gereja harus meneladani, melaksanakan perintah, menghidupi misi dan memiliki fokus pelayanan yang dimiliki oleh Kristus.

Kata Kunci: Eklesiologi; transformatif; trinitarian; gereja; revolusi industri; peradaban 5.0

\section{PENDAHULUAN}

Perkembangan zaman menuntut gereja untuk terus peka terhadap kebutuhan dunia. Tulisan ini berusaha memaparkan pemikiran eklesiologi dalam tataran ontologis dan aksiologis. Lebih dari bentuk dan keberadaan gereja di era society 5.0 (metafisika), namun tantangan yang lebih dalam adalah bagaimanakah makna dan aksi eklesiologis di peradaban baru ini. Gereja diyakini sebagai anugerah Allah bagi dunia untuk menjadi jawaban atas pergulatan manusia di segala zaman. ${ }^{1}$ Praksis gereja mungkin berbeda di setiap zaman, namun natur gereja sebagai agen pembaharuan tidak boleh lekang dimakan waktu. Gereja dipanggil untuk mengisi segala ruang-ruang kehidupan. Tidak ada ruang sakral maupun sekular. Peran gereja dinantikan di sana, secara khusus di masa lajunya perkembangan teknologi di peradaban 5.0 ini.

Perkembangan teknologi dan digitalisasi yang sangat masif di era Revolusi Industri 4.0 segera dijadikan pijakan oleh Jepang untuk segera masuk dalam era revolusi lanjutan yang disebut society 5.0. Pada Januari 2019, Perdana Menteri Shinzo Abe mengumumkan dimulainya peradaban yang lebih humanis (human-centered) demi tercapainya peradaban manusia yang lebih cerdas (super smart society) ${ }^{2}$. Harayama mengatakan bahwa ini adalah sebuah strategi Jepang yang mendesak dalam rangka mengatasi tantangan sosial ${ }^{3}$. Langkah Jepang ini direspons oleh gelombang persetujuan global untuk sama-sama bermigrasi ke peradaban baru.

Era ini digadang-gadang akan mewujudkan masyarakat yang mengintegrasikan dan memanfaatkan teknologi dalam kehidupan sehari-hari bagi kepentingannya. Gagasan ini bukan utopia negara Jepang semata. Bangsa ini telah menyiapkan langkah dan infrastruktur terencana untuk mewujudkannya. Sebagai contoh, sejak tahun 2016, Hitachi-UTokyo Laboratory (H-UTokyo Lab.) mempersiapkan konsep rancang bangun Urban Datarization

\footnotetext{
${ }^{1}$ Bakhoh Jatmiko, "Optimalisasi Fungsi-Fungsi Jabatan Kepemimpinan Gerejawi Sebagai Salah Satu Perwujudan Pelayanan Yang Holistik," Sanctum Domine: Jurnal Teologi 8, no. 2 (2020): 134.

${ }^{2}$ B. Salgues, Society 5.0 Industry of the Future, Technologies, Methods and Tools (London: London: ISTE Ltd., 2018); Mayumi Fukuyama, “Society 5.0: Aiming for a New Human-Centered Society," Japan SPOTLIGHT (2018): 47-50.

${ }^{3}$ Yuko Harayama, "Society 5.0: Aiming for a New Human-Centered Society - Japan's Science and Technology Policies for Addressing Global Social Challenges," Cover Story Collaborative Creation through Global R\&D TRENDS in Hitachi Review 66, no. 6 (2018): 553-559.
}

235 | Copyright $\odot$ 2021, CARAKA, ISSN 2722-1407 (Cetak), 2722-1393 (Online) 
and Cyberspace-Based Data-Driven Planning demi mewujudkan A People-Centric Society ${ }^{4}$. Di dalam peradaban ini, manusia ditempatkan di pusat pusaran teknologi. Ruang siber dan ruang fisik akan bertemu untuk menunjang kehidupan manusia - Sustainable Development Goals (SDGs) ${ }^{5}$. Manusia adalah inti dan pihak yang harus mendapatkan manfaat sebesarbesarnya - people centric society ${ }^{6}$. Di dalam hal inilah muncul persoalan teologis-filosofis yang terkait dengan "agama" A New Humanism ${ }^{7}$. Manusia akan ditempatkan dengan nilai lebih tinggi di atas segala sesuatu.

Selanjutnya, transisi peradaban ini diprediksi akan menghadirkan berbagai persoalan di berbagai level kehidupan. Di tataran perkembangan teknologi, distribusi dan akses teknologi tidak akan memiliki penyebaran yang sama. Negara-negara maju dengan kemampuan finansial besar akan menguasai teknologi, sedangkan negara-negara miskin akan jauh tertinggal di belakang. Kesenjangan teknologi akan terjadi di antara negara kaya dan negara miskin dan berkembang. Di satu sisi akan terbentuk kutub digital illiteracy teknologi, di sisi lain munculnya kutub digital fatigue ${ }^{8}$.

Di era baru ini distribusi kekuasaan dan kekuatan ekonomi bukan lagi ditentukan oleh kekuatan militer, luasnya wilayah atau kekuatan finansial semata. Pihak yang akan mendominasi adalah mereka yang menguasai teknologi dan data (datarization). Dalam Konferensi G20, Osaka, Jepang, Abe mengatakan bahwa data digital akan menjadi penggerak kemajuan ekonomi ${ }^{9}$. Pemikiran tentang Data Free Flow with Trust (DFFT) dan datarization akan bersinggungan dengan persoalan cybersecurity dan cyberwar ${ }^{10}$. Data akan menjadi komoditas berharga yang harus dijaga, sekaligus rentan disalahgunakan. Era ini menjadi era dimana data digital akan menjadi kapital utama.

\footnotetext{
${ }^{4}$ Ryosuke Shibasaki et al., "Integrating Urban Data with Urban Services," in Society 5.0: A PeopleCentric Super-Smart Society (Bunkyo-ku, Tokyo: Springer Open, 2018), 67.

5 Atsushi Deguchi et al., "What Is Society 5.0?," in Society 5.0: A People-Centric Super-Smart Society (Bunkyo-ku, Tokyo: Springer Open, 2018), 1-4.

${ }^{6}$ Atsushi Deguchi and Osamu Kamimura, "Introduction," in Society 5.0: A People-Centric Super-Smart Society (Bunkyo-ku, Tokyo, 2018), xii.

7 “Menghadapi Era Society 5.0, Perguruan Tinggi Harus Ambil Peran - Website LLDIKTI Wilayah V," accessed June 22, 2021, https://lldikti5.kemdikbud.go.id/home/detailpost/menghadapi-era-society-50-perguruantinggi-harus-ambil-peran.

${ }^{8}$ Arne Wiezoreck, Overcoming Societal Challenges and Co-Creating the Future Through Digitalisation and Unity in Diversity Analysis of the Japanese Concept " Society 5 . 0 " and Its Applicability in Germany, 2020, 42.

9 Jack Moss, "Society 5.0: How Will Japan Approach 'Data Capitalism,"” in G20, Osaka Summit, 2019.

${ }^{10}$ S. Serpa and C. Ferreira, "Society 5.0 and Social Development: Contributions to a Discussion. Management and Organizational Studies" 5, no. 4 (2018): 26-31; C. Atkins, I. Ryan, and R. van. Leent, "RealTime, Data-Driven Government: Develop Forward-Thinking, Citizen-Centric Programs.," accessed June 22, 2021, https://www.sap.com/documents/2018/05/dce5d788-057d-0010-87a3-c30de2ffd8ff.html; Arne Wiezoreck, Overcoming Societal Challenges and Co-Creating the Future Through Digitalisation and Unity in Diversity Analysis of the Japanese Concept " Society 5 .0 " and Its Applicability in Germany.
} 
Christian Krell, Thomas Meyer, dan Klaus-Jürgen Scherer melihat fenomena ini sebagai kapitalisme digital ${ }^{11}$. Dengan Penguasaan data digital menjadi kunci penting untuk memenangkan kompetisi di segala bidang. Selain kapitalisme jenis baru, peradaban ini juga diyakini akan menghadirkan paternalisme baru. Aliran kekuasaan dan pengaruh akan mengarah kepada kelompok yang memiliki kekuatan digital ${ }^{12}$. Sistem ini akan memunculkan eksploitasi dan alienasi kelompok yang lebih lemah ${ }^{13}$. Negara maupun pihak yang memiliki fasilitas teknologi, pengalaman literasi dan skill digital akan menjadi kaum borjuis, dan di dalam waktu sama akan menciptakan kelompok-kelompok fatalis yang semakin termarginalisasi.

Tantangan inilah yang sedang diperhadapkan kepada gereja. Ekspresi ontologi gereja sebagaimana diungkapkan oleh Fahey, Collins dan Falconer sebagai anugerah Allah bagi dunia seharusnya dapat dirasakan secara nyata ${ }^{14}$. Melengkapi pemikiran tersebut, Bosch mengatakan bahwa gereja seharusnya aktif bertindak menjadi agen pembaharu di tengahtengah dunia ${ }^{15}$. Pemberitaan kabar baik tentang Yesus Kristus sampai ke ujung bumi adalah focal point misi gereja (Mat. 28:19-20). Namun, merujuk pada Amanat Agung Kristus, gereja juga memiliki mandat untuk "Melakukan segala sesuatu yang telah $\mathrm{Ku}$ perintahkan kepadamu." Hal ini menunjukkan bahwa praksis ekklesiologis gereja tidak terbatas pada pembaharuan spiritual saja dengan "memberitakan, mempertobatkan, membaptiskan." Pillay menegaskan bahwa gereja juga mengemban mandat pembaharuan fisikal dan sosial ${ }^{16}$. Ia melanjutkan bahwa gereja harus hadir di ruang-ruang publik dan terlibat dalam pergulatan manusia, memperbaiki tatanan kehidupan, menjawab persoalan sosial, bahkan memberi andil dalam perbaikan sistem pemerintahan dan politik yang korup ${ }^{17}$.

Di dalam kaitannya dengan panggilan ini, konstruksi eklesiologi eksploratif telah berusaha dibangun guna menghadirkan peran transformatif gereja yang lebih menjawab. Gereja dituntut untuk memiliki sikap dan perspektif yang murni untuk berbagai persoalan kehidupan yang mengemuka termasuk persoalan-persoalan ekonomi, politik, sosial, moral dan

${ }^{11}$ Krell Christian, Thomas Meyer, and Klaus-Jürgen Scherer, "Global: Karl Marx and Digital Capitalism,” IPS Journal (2018), accessed June 22, 2021, https://www.ips-journal.eu/regions/global/karl-marxand-digital-capitalism-2769/.

12 Timo Daum, "Understanding Digital Capitalism - The Times We Live In - An Introduction," accessed June 22, 2021, http://dasfilter.com/gesellschaft/understanding-digital-capitalism-what-time-are-we-living-in-anintroduction.

${ }^{13}$ Christian, Meyer, and Scherer, "Global: Karl Marx and Digital Capitalism."

${ }^{14}$ Michael A. Fahey and Paul M. Collins, Receiving 'The Nature and Mission of the Church'- Ecclesial Reality and Ecumenical Horizons for the Twenty-First Century (New York: Bloomsbury Academic, 2008), 68; A. D Falconer, "The Church: God's Gift to the World: On the Nature an Purpose of the Church," International review of mission 90, no. 359 (2001): 389.

${ }^{15}$ David J. Bosch, Transforming Mission: Paradigm Shifts in Theology of Missions (New York: Orbis Books, 1999), 376.

${ }^{16}$ Jerry Pillay, "The Church as a Transformation and Change Agent," HTS Teologiese Studies / Theological Studies 73, no. 3 (2017): 6.

${ }^{17}$ Pillay, "The Church as a Transformation and Change Agent." 
etis. ${ }^{18}$ Konsepsi tentang misi gereja yang transformatif sebenarnya bukan merupakan diskursus yang baru. Kiprah gereja dalam menghadirkan pembaharuan dan perubahan terlihat dalam sejarah panjang gereja Tuhan di bumi. Bosch berpendapat bahwa sejak zaman para Rasul, gereja (ekklesia) memberikan pelayanan bagi dunia dalam mengejawantahkan panggilannya sebagai agen transformasi ${ }^{19}$. William Ryan mengatakan bahwa Kisah Para Rasul adalah catatan tentang panggilan gereja sebagai Hamba Allah yang melayani dunia ${ }^{20}$.

Kehidupan menggereja di zaman rasuli yang dicatat oleh Alkitab adalah kehidupan yang diwarnai pelayanan kepada peradaban dalam rangka pengabdian diri kepada Allah. Dalam kedudukannya sebagai hamba Allah, gereja bertindak sebagai tangan dan kaki Allah untuk mengasihi dunia. Priana menyebut gereja memiliki peran untuk menghadirkan kerajaan Allah di bumi. ${ }^{21}$ Gereja melayani orang miskin, merangkul kelompok marginal, menyuarakan kesetaraan hak, dan memberi andil didalam mengatasi berbagai persoalan sosial (Kis. 2: 45; $4: 32-35 ; 6: 1-7)$.

Lantas, bagaimanakah gereja memberi makna pada peradaban di era society 5.0 ini? Bagaimanakah pola pelayanan gereja sebagai agen transformasi dengan corak kehambaan yang menjawab kebutuhan masyarakat di era baru ini? Pembahasan di dalam tulisan ini bertujuan untuk melihat peran gereja sebagai agen transformasi dari sepanjang sejarah keberadaannya di dunia ini. Tulisan ini juga berusaha untuk memberikan usulan terhadap kehidupan menggereja yang relevan dengan konteks kebutuhan di era revolusi digital ini dalam kerangka berpikir eklesiologi transformatif.

\section{METODE PENELITIAN}

Pendekatan penelitian ini menggunakan metode kualitatif deskriptif yang melibatkan kajian historis dan eksploratif dari teks Alkitab maupun studi literatur. Penelitian kualitatif adalah sebuah prosedur penelitian yang menghasilkan data deskriptif berupa kata-kata tertulis dari hasil pengamatan 22. Sedangkan pendekatan studi deskriptif analitis digunakan melukiskan suatu keadaan objektif berdasarkan fakta-fakta yang tampak yang kemudian dilakukan pengambilan kesimpulan berdasarkan fakta-fakta tersebut ${ }^{23}$. Sumber data yang

\footnotetext{
${ }^{18}$ Bakhoh Jatmiko, "Hakekat Seksualitas Manusia: Perspektif Gereja Kristen Nazarene Di Abad 21 Terhadap Praktek LGBT,” Sanctum Domine: Jurnal Teologi 4, no. 1 (2016): 29.

${ }^{19}$ Bosch, Transforming Mission: Paradigm Shifts in Theology of Missions.

${ }^{20}$ William F.J. Ryan, "The Church as the Servant of God in Acts," accessed June 22, 2021, https://www.biblicalstudies.org.uk/pdf/scripture/15-32_110.pdf.

${ }^{21}$ I Made Priana, "Misi Gereja Menghadirkan Kerajaan Allah Di Bumi," Sanctum Domine: Jurnal Teologi 4, no. 1 (2016): 12-16.

${ }^{22}$ L J Moleong and T Surjaman, Metodologi Penelitian Kualitatif (Remadja Karya, 2011), 4, https://books.google.co.id/books?id=YXsknQEACAAJ.

${ }^{23}$ I.M.I.P.I. Cahyaningrum, Cara Mudah Memahami Metodologi Penelitian (Deepublish, 2019), 12, https://books.google.co.id/books?id=e--iDwAAQBAJ. 
dikaji berupa teks Alkitab dan literatur yang berkaitan dengan topik yang dibahas. Data akan dikaji dengan analisis historis untuk menemukan peran transformatif gereja di sepanjang sejarah perkembangan peradaban manusia. Sedangkan metode eksploratif-eklesiologis digunakan untuk mendekati teks Alkitab guna mengonstruksi peran gereja dalam terang eklesiologi transformatif.

\section{HASIL DAN PEMBAHASAN}

Pembahasan di dalam bagian ini akan dibagi ke dalam dua bagian. Bagian pertama berkaitan dengan peran gereja yang melayani dunia sebagai implementasi ketundukannya kepada Allah dengan berkontribusi untuk menghadirkan pembaharuan bagi peradaban. Bagian kedua merupakan sebuah pemikiran eklesiologi eksploratif yang berusaha mengusulkan berbagai model kehidupan menggereja yang relevan dengan kebutuhan zaman.

\section{Gereja Sebagai Agen Pembaharu dalam Sejarah Perkembangannya}

\section{Gereja Mula-mula}

Penulis Perjanjian Baru menampilkan Yesus sebagai tokoh dalam gerakan transformatif yang mengkhotbahkan ideologi Kerajaan Allah yang bertolak belakang dengan berbagai kenyataan konteks sosial dimana Ia melayani. Misi pelayanan Yesus disampaikan dengan jelas sebelum Ia mulai melayani. Yesus hadir untuk memberitakan perubahan arah hidup (methanoia - pertobatan), pembaruan, kebebasan, keadilan, kebenaran, dan kesejahteraan (Luk. 4:18-21). Proklamasi yang disampaikan Yesus jelas menampakkan pergulatan spiritual, sosial-ekonomi dan politik yang terjadi pada masa itu. Yesus menunjukkan keberpihakan kepada kaum termarginalkan secara ekonomi, sosial maupun ritual keagamaan (Luk. 6:20-26; Mat. 5:27; Mat. 21:21-32). Dengan tegas Yesus berkonfrontasi dengan sistem kejahatan yang menggurita bahkan menjalar hingga para pemimpin keagamaan (Matt 23:25-33). Hal ini sesuai dengan pendapat Batey yang menjelaskan tentang opresi ekonomi dan sosial dengan kedok keagamaan ${ }^{24}$. Pillay meyakini bahwa berita hadirnya Kerajaan Allah yang disampaikan Yesus bukan hanya tentang pembaruan spiritual, tetapi juga merupakan benih bagi revolusi ekonomi dan reversi sosial masyarakat pada masa itu ${ }^{25}$. Ajaran dan kehidupan Yesus menjadi referensi kehidupan bergereja orang Kristen mula-mula. Tulisan rasuli menunjukkan bagaimana gereja berkiprah bagi dunia di sekitarnya.

${ }^{24} \mathrm{R}$ Batey, Jesus and the Poor (New York: Harper \& Row, 1972), 5.

${ }^{25}$ Pillay, "The Church as a Transformation and Change Agent." 
Peran gereja sebagai agen pembaharu di dalam masyarakat pada abad pertama sangat terlihat. Sebagai bentuk penghambaan diri dan ketaatan kepada teladan Yesus, gereja tidak hanya melulu memperhatikan pembangunan kerohanian iman dan melaksanakan tugas kenabian (Kis. 2;41-44), gereja juga mengambil bagian dalam persoalan-persoalan sosial (Kis. 2: 45; 4:32-35; 6:1-7). Bruce Winter di dalam kajiannya menjelaskan bahwa komunitas yang dikenal dengan nama Kristen (Milik Yesus, Hamba Kristus) sungguh-sungguh mengambil peran transformatif di ruang-ruang publik di konteks masyarakat Greco-Romanum ${ }^{26}$. Orangorang yang telah memeluk identitas baru sebagai hamba dan pengikut Kristus tidak serta merta meninggalkan peran mereka di ranah publik (politeia), namun berusaha menjawab berbagai persoalan yang ada dengan perspektif etis yang baru sebagai hamba Allah. Winter menambahkan bahwa kehidupan menggereja pada abad pertama diwarnai dengan tanggung jawab sosial yang tinggi untuk mengusahakan kesejahteraan kota, menolong yang lemah dan berusaha menunjukkan perbuatan-perbuatan belas kasihan yang nyata ${ }^{27}$. Harnack memberikan dukungan terhadap pemikiran bahwa peran jemaat mula-mula sangat nyata ketika memperhatikan para janda, para yatim piatu, para budak, orang asing, orang yang sakit, orang miskin, dan mereka yang ada di dalam penjara ${ }^{28}$.

\section{Gereja pada Masa Kekaisaran Roma}

Setelah kekristenan menjadi agama resmi kekaisaran Romawi pada era Konstantin, struktur dan pemerintahan Gereja berubah menjadi struktur hierarkis-piramidal yang lebih kompleks sesuai dengan sistem pemerintahan monarki. Suara gereja banyak mempengaruhi kebijakan kekaisaran Roma dalam membuat kebijakan dan pengaturan kehidupan sosial. Gereja mengupayakan peran yang melampaui membran sekat antar ruang privat dan ruang publik dengan memberikan banyak perhatian pada isu-isu yang dihadapi dunia. Perhatian gereja didorong oleh belas kasihan dan dicirikan oleh rasa berkeadilan sosial serta ketundukan dan kasih kepada Allah ${ }^{29}$. Gereja berupaya mempraktikkan tindakan welas asih dalam rangka pengabdian dan ketaatan sebagaimana diajarkan oleh Alkitab dengan menolong orang-orang lemah dan terabaikan.

Pada masa itu, keberpihakan terhadap wanita, anak-anak, dan para budak semakin meningkat. Misalnya di dalam konteks peradilan, wanita tidak lagi dipaksa untuk menjalani pemeriksaan di pengadilan umum; para janda dan yatim piatu mendapat pengecualian

\footnotetext{
${ }^{26}$ Bruce Winter, Seek the Welfare of the City: Christians as Benefactors and Citizens. First-Century Christians in the Graeco-Roman World (Grand Rapids: Eerdmans, 1994), 200.

${ }^{27}$ Winter, Seek the Welfare of the City: Christians as Benefactors and Citizens. First-Century Christians in the Graeco-Roman World.

${ }^{28}$ A. Von Harnack, The Mission and Expansion of Christianity in the First Three Centuries (New York: Harper \& Row, 1967), 148.

${ }^{29}$ Pillay, "The Church as a Transformation and Change Agent." 
perlakuan dalam proses yuridis di pengadilan. Mereka tidak lagi dipaksa untuk hadir dan mendengarkan dakwaan karena pertimbangan keadaan mereka ${ }^{30}$. Pada masa ini juga sebagai bentuk refleksi keyakinan bahwa manusia merupakan citra Allah, maka pertunjukan Gladiator kepada publik dihentikan. Penyaliban sebagai bentuk eksekusi terpidana mati juga tidak dilakukan lagi - sekaligus sebagai bentuk penghormatan pada karya Kristus ${ }^{31}$. Dengan integrasi gereja dan negara pada masa itu, menghadirkan nilai dan budaya baru yang mendorong transformasi kehidupan bermasyarakat semakin meluas ${ }^{32}$. Stanmaugh menambahkan bahwa gereja juga mengambil peran penting pada kebijakan yang berkenaan dengan tata kelola ekonomi masyarakat pada waktu itu ${ }^{33}$.

\section{Gereja pada Abad Pertengahan}

Gereja yang berkembang di Eropa pada abad pertengahan (abad 4-16 - masa kegelapan; aufgabe) berada dalam sistem hierarki sosial feodalisme yang sangat kuat. Distribusi kekuasaan sosiopolitik dijalankan oleh kalangan monarki/bangsawan. Kelompok vassal memiliki hak khusus yang disebut fief atau dalam feodum di dalam bahasa Latin. Di dalam sistem masyarakat seperti ini, pembedaan status sosial ditentukan oleh "nasib" yang ditentukan sejak lahir. Dimana dan di dalam keluarga siapa seseorang dilahirkan, akan menentukan status sosial yang melekat di dalam dirinya. Dampak dari struktur sosial yang demikian ini memiliki kerentanan terhadap eksploitasi dan opresi kepada kelompok dengan faktor hereditas di sublevel yang ada di bawahnya. Hunt dan Sherman menambahkan bahwa pada masa itu kelompok pekerja, pesuruh, dan bahkan budak adalah para proletariat dan rakyat jelata yang memiliki nilai tawar yang lemah dan riskan terhadap penindasan ${ }^{34}$.

Sistem hierarkikal-paternalistik pada struktur masyarakat di abad pertengahan juga berlaku bagi oknum pejabat gereja. Kedudukan agama Kristen sebagai agama negara membuat para klerus juga memiliki atribut kepemimpinan di dalam strata sosial dan pemerintahan ${ }^{35}$. Mereka menduduki peran-peran kunci dalam serikat-serikat pekerja sebagai lembaga penggerak ekonomi pada masa itu. Pengaruh gereja ditunjukkan dengan dorongan untuk menerapkan nilai-nilai etis paternalistik di dalam kehidupan sosial dan ekonomi. Nilai ini

${ }^{30}$ C.N Cochrane, Christianity and Classical Culture: A Study of Thought and Action from Augustus to Augustine (New York: Oxford University Press, 1974), 191-193.

${ }^{31}$ Cochrane, Christianity and Classical Culture: A Study of Thought and Action from Augustus to Augustine.

${ }^{32}$ V. Burrus, Late Ancient Christianity, a People's History of Christianity (Mineapolos, MN: Fortress Press, 2005), 42-54. 1986), 204

${ }^{33}$ J. Stanmaugh and D Balch, The Social World of the First Christians (Great Britain: Anchor Press,

${ }^{34}$ E.K. Hunt and H.J Sherman, Economics: An Introduction to Traditional and Radical Views (New York: Harper \& Row, 1981), 4.

${ }^{35}$ Pillay, "The Church as a Transformation and Change Agent." 
mengajarkan bahwa kekayaan dan kemakmuran tidak ditentang, namun ketamakan, egoisme, iri hati, hawa nafsu akan kekayaan adalah hal yang ditentang. Harta dan kekayaan harus digunakan untuk membantu yang miskin. Di sisi lain, gerakan pembaharuan yang lebih kuat justru terjadi di luar gereja sebagai lembaga. Munculnya tokoh pelopor seperti Agustinus dari Hippo atau berkembangnya gerakan monastik menjadi tonggak penting di dalam propagasi gerakan transformasional di dalam gereja.

Agustinus dari Hippo adalah salah satu tokoh eklesiologi transformatif pada era ini, yang dikemudian dikenal sebagai arsitek dari doktrin belas kasihan (the doctrine of charity) ${ }^{36}$. Konstruksi eklesiologi Agustinus didasarkan pada refleksi terhadap karya Allah yang menghambakan diri menjadi manusia dengan sebuah misi pembaharuan ${ }^{37}$. Ia meyakini pemikiran bahwa gereja harus terlibat di dalam dunia; gereja bagi dunia dan bukan dunia bagi gereja sebagai bentuk meneladani Kristus Sang Hamba ${ }^{38}$. Dengan kata lain, gereja harus mengambil andil di dalam gerakan transformasi sosial, memperhatikan orang miskin dengan upaya belas kasihan. Ketaatan dan penghambaan diri kepada Allah harus ditunjukkan pada tindakan belas kasihan kepada orang miskin.

Selain pemikiran yang mengemuka di atas, pemikiran eklesiologi transformatif pada abad pertengahan sangat terkait dengan perkembangan gerakan monastik di dalam gereja (abad ke 5-12). Kendati pada umumnya gerakan monastri dikenal dengan memisahkan pemisahan diri dari sistem dunia dengan membentuk komunitas sosial dengan nilai-nilai idealis mereka sendiri, namun pengaruh gerakan ini memberi dampak signifikan pada transformasi sosial khususnya masyarakat Eropa. Ellison mengatakan bahwa para rahib sangat dihormati pada waktu itu ${ }^{39}$. Gaya hidup mereka menjadi teladan khususnya bagi masyarakat kelas bawah. Kemudian, keberadaan monastri sangat memberi arti karena di sana bukan hanya diajarkan menjadi pusat pembelajaran iman Kristen tetapi juga berbagai bidang keilmuan dan keterampilan lain ${ }^{40}$.

Dari gerakan inilah ungkapan ora et labora berasal. Gerakan mendirikan biara-biara (monastry) berusaha mengupayakan keselarasan antara teologi dan praksis, iman dan pengembangan ilmu pengetahuan, kerohanian dan sosial ekonomi. Para rahib dilatih untuk mengembangkan kehidupan yang mampu menjawab pergulatan dunia sebagai bagian dari tugas pemberitaan Injil dan ketaatan kepada Allah. Upaya ini berusaha untuk membuat gereja

${ }^{36}$ R Sider, Evangelicals and Development: Towards a Theology of Social Shange, Contemporary Issues in Social Ethics, 2nd ed. (Fitzroy Falls, NSW, Australia: The Paternoster Press, 1981), 20.

${ }^{37}$ Pillay, "The Church as a Transformation and Change Agent."

${ }^{38}$ Sider, Evangelicals and Development: Towards a Theology of Social Shange, Contemporary Issues in Social Ethics.

${ }^{39}$ E.J Elliston, Christian Relief and Development: Developing Workers for Effective Ministry (Dallas, Texas: Word Publishing, 1989), 7.

${ }^{40}$ W Cannon, History of Christianity in the Middle Ages (Nashville: Abingdon, 1960), 16. 
lebih berperan bagi dunia. Neibuhr mengatakan bahwa sistem monastri yang bermunculan pada masa itu telah menyelamatkan gereja dari sikap diam, petrifikasi, serta kehilangan visi dan misinya ${ }^{41}$. Biara-biara didirikan sebagai komunitas religio-sosial yang berupaya hidup dengan nilai dan tatanan untuk menciptakan sistem kemasyarakatan yang baru di tengah sistem sosial yang korup dan cemar. Di dalam kelompok ini mereka belajar mengerjakan pekerjaan-pekerjaan untuk menopang kehidupan mereka, tetapi juga mengembangkan kebudayaan serta pendidikan masyarakat. Di dalam praktiknya, mereka berusaha untuk terus menghubungkan kemantapan kerohanian dengan praktik hidup sehari-hari. Mereka didik untuk dapat menghadirkan jawaban bagi dunia, melaksanakan pembaharuan dan membuat perubahan sebagai wujud pengabdian kepada Allah ${ }^{42}$.

\section{Gereja Pasca Reformasi}

Gereja pada era reformasi ada di dalam konteks revolusi industri Eropa, berkembangnya rasionalisme, politik dan ekonomi kapitalisme maupun merkantilisme sebagai kebijakan politik negara imperialis. Pada masa ini kota-kota maupun daerah-daerah penyangga semakin berkembang. Hal ini mengakibatkan mobilisasi demografi dengan alasan ekonomi dan status sosial. Di sisi lain, orang-orang yang lebih beruntung dengan uang dan modal memegang peranan penting di dalam menciptakan kapitalisme modern. Politik dagang merkantilisme dan kapitalisme membuat kesenjangan antara si kaya dan si miskin semakin besar. Segmentasi strata sosial di masyarakat sangat terlihat. Pemimpin gereja menduduki strata sosial yang paling terhormat, kemudian para bangsawan di bawahnya dan yang paling rendah adalah kelompok rakyat jelata. Di dalam bidang ekonomi muncul terminologi lapisan sosial yang baru yaitu kelompok borjuis dan kelompok buruh. Kepincangan sosial ini akhirnya menjadi gejolak sosial yang tidak dapat diredam. Misalnya, pecahnya revolusi Perancis dengan menyerukan liberte, egalite dan franternite.

Di dalam konteks sosio-politik dan ekonomi seperti inilah gereja di era reformasi berada. Berkembangnya rasionalisme memunculkan pola pikir kritis yang menyampaikan kritis sosial atas situasi yang terjadi termasuk kepada gereja. Marthin Luther dengan tegas menentang "kapitalisme di dalam gereja" yang memungut bunga ${ }^{43}$. Ia menyebut gereja sebagai kapitalis penindas, tidak berharga, dan harus bertobat karena sudah menyimpang dari panggilan kehambaannya ${ }^{44}$. Kritik Luther bukan hanya ditujukan pada persoalan-persoalan

\footnotetext{
${ }^{41}$ Bosch, Transforming Mission: Paradigm Shifts in Theology of Missions.

${ }^{42}$ Ibid.

${ }^{43}$ Ulrich Duchrow, Alternatives to Global Capitalism: Drawn from Biblical History, Designed for Political Action (Utrecht: International Books with Kairos Europe, 1995), 220-221.

${ }^{44}$ Duchrow, Alternatives to Global Capitalism: Drawn from Biblical History, Designed for Political
} Action. 
dogmatis saja, tetapi juga pada ranah sosial. Ia menyuarakan perilaku alternatif yang relevan terkait dengan persoalan-persoalan di kelompok grassroot. Luther meyakini bahwa orang Kristen memiliki kewajiban untuk tunduk pada dua otoritas yang berbeda, yaitu otoritas spiritual (sebagai hamba Allah) dan otoritas sipil (sebagai hamba negara) ${ }^{45}$. Orang Kristen tidak boleh memiliki sikap eksklusif dengan memilih ketundukan pada salah satu otoritas saja. Ketaatan pada otoritas Allah juga harus ditunjukkan pada peran di otoritas sipil dalam perubahan sosial.

John Calvin, seperti Marthin Luther juga menjadi tokoh reformasi sekaligus memberikan penekanan pada peran gereja sebagai agen transformasi. Calvin mendemonstrasikan pemikiran transformatifnya secara nyata khususnya di Genewa. Ia meyakini adanya keterhubungan yang kuat antara cara pandang keagamaan dengan transformasi masyarakat ${ }^{46}$. Keyakinan ini ia sampaikan dengan kesadaran bahwa masyarakat di mana ia ada dalam keadaan krisis baik secara moral dan spiritual. Kehidupan menggereja harus membawa dampak transformatif bagi masyarakat.

Konsep dasar Calvin dalam memandang mandat pembaharuan berpijak pada keyakinan bahwa Allah adalah legislateur et roy (Penguasa/Tuan) atas alam semesta dan manusia adalah hamba-Nya ${ }^{47}$. Allah memiliki otoritas atas segala ciptaan - termasuk masyarakat gereja dan di luar gereja. Darah Kristus yang dicurahkan di kayu salib menaklukkan segala sesuatu di bawah kuasa dan otoritasnya ${ }^{48}$. Sehingga, karya pembaharuan Allah juga harus terjadi di semua aspek kehidupan di alam semesta ini. Mandat pembaharuan di dalam gereja diwujudkan dengan perannya sebagai hamba yang menjembatani Kristus yang bertakhta (regnum Chirti) dengan "dunia sekuler" 49 . Baginya, gereja adalah perpanjangan takhta Kristus dengan transformasi spiritualitas pribadi, maupun transformasi wajah bumi dengan memenuhinya dengan pengenalan akan Kristus ${ }^{50}$. Pengenalan tersebut akan membentuk komunitas Kristen yang sejati dan dengan cara itulah transformasi akan terjadi.

Berkaitan dengan pergulatan sosial, Calvin melihat kemiskinan sebagai fenomena sosial yang serius. Dia meyakini bahwa kemiskinan merupakan bagian dari tanggung jawab gereja yang harus berperan untuk mengatasinya ${ }^{51}$. Di dalam pelayanannya, Calvin sangat dekat dengan kelompok termarginalkan, menggalang dana bagi yang membutuhkan dan melakukan lobi kepada pihak berwenang untuk bertindak bagi orang-orang miskin. Di dalam

${ }^{45}$ A.E McGrath, Reformation Thought an Introduction, , . (Oxford, New York: Wiley-Blackwell, 2012), 20.

${ }^{46}$ Pillay, "The Church as a Transformation and Change Agent."

${ }^{47}$ W.J. Bouwsma, John Calvin: A Sixteenth Century Portrait (New York: Harper \& Row, 1988), 192.

${ }^{48}$ John Calvin, "Khotbah No. 45 Dalam Ulangan," n.d., 426-427.

${ }^{49}$ D.K. McKim, Readings in Calvin's Theology (Grand Rapids, MI: Baker Book House, 1984), 175.

${ }^{50}$ McKim, Readings in Calvin's Theology.

${ }^{51}$ Pillay, "The Church as a Transformation and Change Agent." 
pergerakannya, Calvin sebagai teolog dan pendeta juga terlibat di dalam berbagai bidang kehidupan sehari-hari.

Keterlibatan Calvin di dalam kehidupan sehari-hari bukan hanya berkaitan dengan persoalan kesejahteraan dan kemiskinan. Peranan Calvin sangat nyata di dalam perumusan kebijakan dan peraturan publik terkait dengan bidang sosial dan ekonomi serta kehidupan sehari-hari di Genewa ${ }^{52}$. Sumbagsihnya terlihat di dalam bidang pelayanan publik seperti rumah sakit, hukum perlindungan (sumptuaty laws), serta berbagai peraturan tentang bisnis dan industri yang terkait dengan pengaturan upah buruh dan pekerja ${ }^{53}$. Di bidang lain, ia memberikan usulan dalam peraturan pembuatan railing di tangga maupun balkon untuk keamanan anak-anak. Perapian dan cerobong asap diatur sedemikian rupa untuk membuat kota lebih bersih dan teratur ${ }^{54}$. Ia juga mendirikan sekolah gratis lintas gender pertama.

Gerakan Reformasi gereja menjadi kebangkitan pemikiran eklesiologi transformatif. Gerakan pembaharuan tidak hanya memperbarui dan mengubah gereja dan meninggalkan dunia. Tetapi, reformasi telah melakukan intervensi dramatis dalam sejarah peradaban dunia. Gerakan ini telah membawa perubahan radikal dalam aspek spiritual, sosial, politik dan ekonomi untuk masuk dalam era baru dunia. Oleh karena itu, tidak berlebihan jika Van Der Walt mengatakan bawa bahwa Luther, Calvin, Knox, Zwingli dan lainnya adalah produk latar belakang sosial-ekonomi dan politik mereka yang kemudian berinisiatif untuk melakukan pembaharuan di dalamnya ${ }^{55}$. Pillay menyebut masa reformasi sebagai sebuah keajaiban teologis dimana perhatian khusus Allah terhadap orang miskin dan tertindas seperti dicatat di dalam Alkitab kembali ditemukan ${ }^{56}$. Pengaruh teologi ini yang kemudian diteruskan oleh gereja-gereja oikumenis di abad 20 dan 21 ini.

\section{Gereja sebagai Hamba yang Melayani di Era Society 5.0}

Penelusuran di atas menunjukkan bahwa mandat pembaharuan (transformatif) tidak pernah lepas dari sejarah perkembangan gereja. Dengan berbagai dinamika dan pergumulannya di rentang sejarah, gereja berusaha menghidupi naturnya di dalam menghadirkan pembaharuan bagi kehidupan sebagai wujud penghambaan diri kepada otoritas Allah. Teolog eklesiologi transformatif selalu meyakini bahwa gereja adalah anugerah Allah bagi dunia. Gereja bukan hanya dimiliki secara eksklusif oleh sekelompok orang tertentu,

${ }^{52}$ McKim, Readings in Calvin's Theology.

53 J.E. Olson, Calvin and Social Welfare (London: Associated University Presses, 1989), 12-13.

${ }^{54}$ Pillay, "The Church as a Transformation and Change Agent."

${ }^{55}$ B.J. Van Der Walt, Anatomy of Reformation (Potchefstroom: Potchefstroom University for CHE, 1991), 211.

${ }^{56}$ Pillay, "The Church as a Transformation and Change Agent." 
tetapi gereja hadir untuk menjadi agen pembaharuan bagi pergumulan dan kerusakan sistem di dunia.

Berbagai pencapaian dan kemajuan di dunia tampaknya tidak serta merta menyelesaikan persoalan-persoalan di dunia. Ekklesia itu sendiri tidak hanya ada ketika orang bertemu atau disebut persekutuan, tetapi juga memasuki semua bidang kehidupan, termasuk semua kegiatan ekonomi, yang menyatakan bahwa ekklesia adalah milik Allah dan suatu ciptaan baru, mencirikan masyarakat egaliter, adil dan yang penuh solidaritas. Ini berarti bahwa pendekatan kenabian dipertahankan secara radikal sehingga jalan mesianis untuk menjadi gereja yang sesungguhnya ${ }^{57}$. Dalam ekklesia tidak ada ketidakadilan, tetapi sebaliknya keadaan yang holistik ${ }^{58}$.

Peran gereja sebagai Hamba Allah yang melayani dapat diwujudkan dengan beberapa pengejawantahan yang menyentuh kehidupan manusia. Pendekatan eksploratif menemukan pola pelayanan gereja sebagai agen transformasi dengan corak kehambaan yang menjadikan Kristus sebagai model utamanya. Gagasan eklesiologi trinitarian ini yang berusaha dijabarkan dalam relevansinya dengan peradaban 5.0.

\section{Meneladani Kristus}

Yesus Kristus adalah teladan Hamba Allah yang sejati. Ketaatan, ketundukan, dan seluruh keberadaan-Nya didedikasikan supaya kehendak Bapa terlaksana di bumi. Kristus yang menghamba menjadi model bagi gereja yang bersentuhan dengan pergumulanpergumulan dunia. Ketundukan dan kepatuhan Kristus kepada Bapa bukan hanya berkaitan dengan dimensi personal, tetapi tercermin dengan tindakan dan karya-Nya untuk mengasihi orang miskin, memerdekakan kaum tertindas, dan merestorasi tatanan sosial (Luk. 14). Misi Kristus digerakkan dengan ketundukan pada kehadiran Roh Bapa di dalam hidupnya - Roh Tuhan ada pada-Ku. Pelayanan Kristus merupakan perwujudan dari ketundukan pada pimpinan dan otoritas Bapa melalui Roh-Nya.

Eklesiologi trinitarian menjadikan Kristus sebagai teladan dalam kehidupan menggereja. Agustinus mengatakan bahwa aspek natur dan misi gereja adalah De Trinitate (On the Trinity). Oleh karena itu, sebagaimana Kristus taat pada kehendak Bapa, demikian juga gereja sebagai hamba Allah juga harus menunjukkan ketaatan yang sama. Spaulding II dan Spaulding III mengatakan bahwa habitus gereja yang meneladani Kristus dalam menjadi

${ }^{57}$ Duchrow, Alternatives to Global Capitalism: Drawn from Biblical History, Designed for Political Action.

${ }^{58}$ John C. Simon and Stella.Y.E.Pattipeilohy., Pembangunan Ekonomi Gereja: Refleksi Atas Praksis Teologi Ekonomi GPIB (PT Kanisius, n.d.), 12, https://books.google.co.id/books?id=z5\%5C_6DwAAQBAJ. 246 | Copyright@ 2021, CARAKA, ISSN 2722-1407 (Cetak), 2722-1393 (Online) 
berkat di ruang publik adalah tanda ketundukan gereja pada misi Allah ${ }^{59}$. Haight menambahkan pada Spaulding dan Spaulding bahwa habit sosial dari gereja adalah bentuk dari refleksi pembelajaran atas kehidupan Yesus Kristus orang Nazaret selama melayani di dunia ${ }^{60}$.

Model pelayanan gereja di dalam peradaban manusia adalah sebuah metanaratif karya pembaharuan Allah dari masa ke masa. Kisah ini bukan hanya kisah Yesus Kristus orang Nazaret itu, tetapi juga menjadi kisah gereja yang menjadi agen pembaharuan. Di dalam pelayanan-Nya di bumi, Kristus hadir sebagai figur yang berkeadilan (The equitable Jesus) menghadirkan jawaban bagi pergulatan dan kesesakan yang dihadapi masyarakat dalam konteks pada waktu itu. ${ }^{61}$ Demikian juga, di dalam kepincangan sosial yang ada di tengah masyarakat, gereja harus mengikuti jejak-jejak yang ditinggalkan Kristus di ruang-ruang publik untuk melayani masyarakat. Kehadiran gereja di Era society 5.0 memiliki panggilan untuk menghadirkan sentuhan Allah di tengah-tengah derasnya arus humanisme, kapitalisme, paternalisme dan kolonialisme modern.

\section{Melaksanakan Perintah Kristus}

Gereja didirikan oleh Yesus dan dibangun atas dirinya (Mat. 16:18). Gereja adalah milik Kristus dan keberadaannya harus menyenangkan Sang Pemilik dengan cara menaatiNya. Seperti disinggung sebelumnya, Amanat Agung untuk menjadikan semua bangsa menjadi murid Kristus adalah focal point misi gereja (Mat. 28:19-20). Namun, mandat ini juga menyertakan perintah untuk "Melakukan segala sesuatu yang telah $\mathrm{Ku}$ perintahkan kepadamu."

Perutusan gereja sebagai pelaksana Amanat Agung harus dipahami secara lebih inklusif. Peran praksis ekklesiologis gereja tidak terbatas pada pembaharuan spiritual saja dengan "memberitakan, mempertobatkan, membaptiskan" dunia, tetapi juga menghadirkan pembaharuan fisikal dan sosial. Gereja diperintahkan Yesus untuk menjadi komunitas yang bersaksi. Gereja dipanggil untuk lisankan kesaksian; memproklamasikan (kerygma) dan untuk memperagakan kesaksian di tengah-tengah dunia ${ }^{62}$. Peran ini sangat krusial dilakukan oleh gereja di tengah-tengah masyarakat digital ini.

${ }^{59}$ Hendry W. Spaulding and Hendry W. Spaulding, "Trinitarian Identity of the Church's True Foundation," in The Essential Church: A Wesleyan Ecclesiologi (Kansas City: Beacon Hill, 2014), 41-43.

${ }^{60}$ Roger D. Haight, "Christian Community in History," in Ecclesial Existence (New York: Continuum, 2008).

${ }^{61}$ Bakhoh Jatmiko, “The Equitable Jesus," SANCTUM DOMINE: JURNAL TEOLOGI 5, no. 1 (2017): 69-79.

${ }^{62}$ David Busic, "The Church as a Witnessing Community," in The Essential Church: A Wesleyan Ecclesiologi (Kansas City: Beacon Hill, 2014), 167-170. 
Agama baru A New Humanism yang ada dibalik semangat pembaharuan peradaban ini sungguh-sungguh perlu diwaspadai. Manusia yang ditempatkan di pusat pemanfaatan teknologi lambat laun dapat menjadikan manusia tuhan atas dirinya, maupun sebaliknya; kebergantungan akan teknologi yang akan membuatnya menjadi tuhan atas manusia. Selain hal tersebut, Deidre menambahkan bahwa masyarakat hipermodern akan diwarnai dengan the fusion horizon sehingga akan sulit untuk menemukan kebenaran hakiki ${ }^{63}$. Manusia akan menjadi pengukur kebenaran bagi dirinya sendiri. Relativisme dan subjektivisme akan mewarnai pola berpikir masyarakat.

Di dalam konteks inilah suara kenabian gereja diperlukan. Gereja hadir bagi dunia, melayani dunia dengan memberitakan kebenaran. Penghambaan diri gereja ditunjukkan dengan kerelaannya menjadi saksi sebagai garam dan terang Allah di tengah-tengah dunia ${ }^{64}$. Penghambaan diri gereja adalah wujud kasihnya kepada Kristus (Yoh. 14:15).

\section{Menghidupi Misi Kristus}

Gereja sebagai hamba Allah dipanggil untuk menghidupi misi Kristus. Pasca kebangkitan-Nya, Kristus menegaskan kontinuitas misi Allah kepada para murid-Nya. Firmannya: "Sama seperti Bapa mengutus Aku, demikian juga sekarang Aku mengutus kamu" (Yoh. 20:21). Misi yang dijalankan gereja adalah misi yang sama, yang pernah diberikan kepada Kristus.

Pemercayaan ini sangat berkaitan dengan janji penyertaan dan kuasa yang diberikan Kristus kepada gereja-Nya (Mat. 28: 21; Mrk. 16:17-18; Kis. 1:8). Di dalam menunaikan misi Kristus, gereja membawa kuasa dari Allah. Gibbs dalam the Church Today melihat gereja sebagai kekuatan formatif dan transformatif yang mampu mengubah ketidakadilan sosial di masyarakat ${ }^{65}$. Ia berpendapat bahwa di dalam menjalankan peran transformatif, gereja bukan hanya harus Alkitabiah di dalam pesan, tetapi juga di dalam misinya (biblically true to its message and its mission) ${ }^{66}$. Selaras dengan pemikiran tersebut, Smith menambahkan bahwa kuasa pembaharuan yang dilakukan gereja menjadi fenomena pendorong sehingga pemikiran ini menjadi pemikiran yang lebih global ${ }^{67}$. Lebih lanjut, Smit mengatakan bahwa untuk

${ }^{63}$ Deidre Brower Latz, "Cultural Correlation the Postmodern Marks of the Church," in The Essential Church: A Wesleyan Ecclesiologi (Kansas City: Beacon Hill, 2014), 84-93.

${ }^{64}$ Busic, "The Church as a Witnessing Community."

${ }^{65}$ E. Gibbs, The Church Today: Church Next: Quantum Changes in How We Do Ministry (Chicago, IL: InterVarsity Press, 2001).

${ }^{66}$ Ibid.

${ }^{67}$ D.J. Smit, "Challenges for Reformed Churches in Africa: A Contemporary Narrative'," International Journal for the Study of the Christian Church 8, no. 4 (2008): 319-336. 
menjadi kekuatan yang mengubahkan, gereja harus berwujud, terlihat dan mengejawantah di dalam struktur sosial ${ }^{68}$.

Kapitalisme, paternalime dan kolonialisme digital tampaknya lebih susah diterobos oleh mekanisme pembaharuan konvensional. Kekuatan ini bukan seperti rezim yang terlihat dan ditumbangkan dengan kudeta, perlawanan, atau demonstrasi. Karunia dan kuasa Allah yang diperlukan untuk menghadirkan perubahan di tengah-tengah masyarakat. Karakter dan spiritualitas manusia akan tergerus di tengah derasnya arus globalisasi dan digitalisasi. Kuasa transformatif dari Allah tersebut yang diperlukan untuk menghadirkan perubahan.

\section{Mengubah Fokus Pelayanan}

Perubahan peradaban menuntut perubahan baik paradigma maupun model pelayanan gereja. Gereja ditantang untuk melangkah keluar dari zona nyaman sebelumnya dan diajak untuk melakukan terobosan-terobosan untuk membuatnya tetap relevan dan menjadi jawaban. Berikut adalah beberapa fokus yang seharusnya diubah gereja di dalam melayani masyarakat di society 5.0.

\section{Dari pelayanan altar ke pelayanan latar.}

Digitalisasi telah merobohkan tembok-tembok pelayanan gereja. Integrasi teknologi digital di dalam pelayanan membuat batas-batas organisasi dan denominasi hampir tidak tampak, Oleh karena itu, di era digital ini, tampaknya tidak lagi relevan bagi gereja untuk menghabiskan energi dan sumber dayanya untuk berkutat dengan pelayanan-pelayanan intern yang dibatasi oleh empat dinding gereja. Kebutuhan akan pelayanan kasih Allah ada di mana-mana. Sudah waktunya gereja kembali meneladani Kristus Sang Hamba sejati yang melayani di tepi danau, ladang, jalan-jalan dan bahkan di rumah cukai. Tantangan besar bagi gereja adalah bagaimana gereja memberikan dirinya menjadi masyarakat luas. Peran dan pelayanan gereja bagi masyarakat luas (inklusif) dan tidak hanya terbatas kepada anggota jemaat saja (eksklusif).

\section{Dari dunia bagi gereja ke gereja bagi dunia.}

Dunia bagi gereja berarti gereja bertindak sebagai penerima dan pihak yang pasif menunggu. Sedangkan gereja bagi dunia berarti terdapat inisiatif dan aksi nyata dari gereja yang didorong oleh kesadaran panggilannya untuk melayani dunia. Berkaitan dengan ini Rick Warren dengan tegas mengatakan bahwa di dalam pergumulan mendesak yang dihadapi oleh dunia, yang

${ }^{68}$ Smit, "Challenges for Reformed Churches in Africa: A Contemporary Narrative'." 
diperlukan gereja bukan kredo tetapi tindakan (not creeds but deeds) ${ }^{69}$. Meskipun keyakinan iman dan pernyataan dogmatik sangat diperlukan, namun tentu Warren hendak menekankan bahwa gereja perlu menunjukkan tindakan nyata sebagai pembawa mandat pembaharuan.

\section{Dari pelayanan parsial ke pelayanan holistik.}

Gereja sebagai institusi yang didirikan Yesus di bumi mempunyai kedudukan dan peran yang penting dalam misi Allah bagi manusia. Gereja seharusnya selalu relevan dan mampu hadir sebagai pengantara maupun penyelenggara pembaharuan kehidupan. Dikotomi dan pemisahan dimensi rohani dan sekular (sacred - secular), batasan ruang privat dan publik, dan pekerjaan dengan nilai mulia dan kurang mulia hendaknya tidak lagi dipegang secara kaku oleh gereja. Secara ontologis, gereja harus mampu memberi makna bagi dunia di dalam seluruh aspek pergumulan yang dihadapinya (holistik) sebagaimana tugasnya sebagai garam dan terang dunia.

\section{KESIMPULAN}

Kajian di dalam makalah ini berusaha mengetengahkan pendekatan eksploratif dalam bingkai pemikiran eklesiologi transformatif trinitarian. Kajian ini menemukan peran transformatif gereja dari masa ke masa. Mandat ini telah menjadi DNA gereja sejak ia dilahirkan di tengah-tengah dunia. Panggilan untuk tetap relevan terus melekat pada gereja. Perubahan zaman membuat gereja harus bergerak dan berakselerasi dalam ranah teologis maupun aksiologis. Peran gereja sebagai agen pembaharu sungguh-sungguh dinantikan ditengah-tengah euphoria pencapaian manusia yang menyisakan kerentanan peradaban itu sendiri. Gereja harus sadar bahwa dirinya adalah hamba yang menunjukkan ketaatan kepada Allah melalui karya nyata di tengah-tengah dunia. Menghadirkan perubahan, memberikan harapan dan menyatakan sentuhan Allah bagi dunia.

\section{DAFTAR PUSTAKA}

Arne Wiezoreck. Overcoming Societal Challenges and Co-Creating the Future Through Digitalisation and Unity in Diversity Analysis of the Japanese Concept " Society 5 . 0 " and Its Applicability in Germany, 2020.

Atkins, C., I. Ryan, and R. van. Leent. "Real-Time, Data-Driven Government: Develop Forward-Thinking, Citizen-Centric Programs.” Accessed June 22, 2021. https://www.sap.com/documents/2018/05/dce5d788-057d-0010-87a3-c30de2ffd8ff.html. Batey, R. Jesus and the Poor. New York: Harper \& Row, 1972.

${ }^{69}$ R. Warren, The Purpose Driven Church: Every Church Is Big in God's Eyes (Michigan: Zondervan Press, 1995). 
Bosch, David J. Transforming Mission: Paradigm Shifts in Theology of Missions. New York: Orbis Books, 1999.

Bouwsma, W.J. John Calvin: A Sixteenth Century Portrait. New York: Harper \& Row, 1988. Brower Latz, Deidre. "Cultural Correlation the Postmodern Marks of the Church." In The Essential Church: A Wesleyan Ecclesiologi, 84-93. Kansas City: Beacon Hill, 2014.

Burrus, V. Late Ancient Christianity, a People's History of Christianity. Mineapolos, MN: Fortress Press, 2005.

Busic, David. "The Church as a Witnessing Community." In The Essential Church: A Wesleyan Ecclesiologi, 167-175. Kansas City: Beacon Hill, 2014.

Cahyaningrum, I.M.I.P.I. Cara Mudah Memahami Metodologi Penelitian. Deepublish, 2019. https://books.google.co.id/books?id=e--iDwAAQBAJ.

Calvin, John. "Khotbah No. 45 Dalam Ulangan," n.d.

Cannon, W. History of Christianity in the Middle Ages. Nashville: Abingdon, 1960.

Christian, Krell, Thomas Meyer, and Klaus-Jürgen Scherer. "Global: Karl Marx and Digital Capitalism.” IPS Journal (2018). Accessed June 22, 2021. https://www.ipsjournal.eu/regions/global/karl-marx-and-digital-capitalism-2769/.

Cochrane, C.N. Christianity and Classical Culture: A Study of Thought and Action from Augustus to Augustine. New York: Oxford University Press, 1974.

Daum, Timo. "Understanding Digital Capitalism - The Times We Live In - An Introduction." Accessed June 22, 2021. http://dasfilter.com/gesellschaft/understanding-digitalcapitalism-what-time-are-we-living-in-an-introduction.

Deguchi, Atsushi, Chiaki Hirai, Hideyuki Matsuoka, Taku Nakano, Kohei Oshima, Mitsuharu Tai, and Shigeyuki Tani. "What Is Society 5.0?" In Society 5.0: A People-Centric SuperSmart Society, 1-24. Bunkyo-ku, Tokyo: Springer Open, 2018.

Deguchi, Atsushi, and Osamu Kamimura. "Introduction.” In Society 5.0: A People-Centric Super-Smart Society, Springer Open. Bunkyo-ku, Tokyo, 2018.

Duchrow, Ulrich. Alternatives to Global Capitalism: Drawn from Biblical History, Designed for Political Action. Utrecht: International Books with Kairos Europe, 1995.

Elliston, E.J. Christian Relief and Development: Developing Workers for Effective Ministry. Dallas, Texas: Word Publishing, 1989.

Fahey, Michael A., and Paul M. Collins. Receiving 'The Nature and Mission of the Church'Ecclesial Reality and Ecumenical Horizons for the Twenty-First Century. New York: Bloomsbury Academic, 2008.

Falconer, A. D. "The Church: God's Gift to the World: On the Nature an Purpose of the Church." International review of mission 90, no. 359 (2001): 389-400.

Gibbs, E. The Church Today: Church Next: Quantum Changes in How We Do Ministry. Chicago, IL: InterVarsity Press, 2001.

Haight, Roger D. "Christian Community in History." In Ecclesial Existence. New York: Continuum, 2008.

Harayama, Yuko. "Society 5.0: Aiming for a New Human-Centered Society - Japan's Science and Technology Policies for Addressing Global Social Challenges.” Cover Story Collaborative Creation through Global R\&D TRENDS in Hitachi Review 66, no. 6 (2018): 553-559.

Von Harnack, A. The Mission and Expansion of Christianity in the First Three Centuries. New York: Harper \& Row, 1967.

Hunt, E.K., and H.J Sherman. Economics: An Introduction to Traditional and Radical Views. 
New York: Harper \& Row, 1981.

Jatmiko, Bakhoh. "Hakekat Seksualitas Manusia: Perspektif Gereja Kristen Nazarene Di Abad

21 Terhadap Praktek LGBT.” Sanctum Domine: Jurnal Teologi 4, no. 1 (2016): 29-39.

_. "Optimalisasi Fungsi-Fungsi Jabatan Kepemimpinan Gerejawi Sebagai Salah Satu

Perwujudan Pelayanan Yang Holistik.” Sanctum Domine: Jurnal Teologi 8, no. 2 (2020):

$133-156$.

—. "The Equitable Jesus." SANCTUM DOMINE: JURNAL TEOLOGI 5, no. 1 (2017):

69-80.

Mayumi Fukuyama. "Society 5.0: Aiming for a New Human-Centered Society." Japan

SPOTLIGHT (2018): 47-50. http://www8.cao.go.jp/cstp/.

McGrath, A.E. Reformation Thought an Introduction, , . Oxford, New York: Wiley-Blackwell, 2012.

McKim, D.K. Readings in Calvin's Theology. Grand Rapids, MI: Baker Book House, 1984.

Moleong, L J, and T Surjaman. Metodologi Penelitian Kualitatif. Remadja Karya, 2011.

https://books.google.co.id/books?id=YXsknQEACAAJ.

Moss, Jack. "Society 5.0: How Will Japan Approach 'Data Capitalism."” In G20, Osaka

Summit, 2019.

Olson, J.E. Calvin and Social Welfare. London: Associated University Presses, 1989.

Pillay, Jerry. "The Church as a Transformation and Change Agent." HTS Teologiese Studies /

Theological Studies 73, no. 3 (2017): 1-12.

Priana, I Made. "Misi Gereja Menghadirkan Kerajaan Allah Di Bumi." SANCTUM DOMINE: JURNAL TEOLOGI 4, no. 1 (2016): 12-27.

Ryan, William F.J. "The Church as the Servant of God in Acts.” Accessed June 22, 2021.

https://www.biblicalstudies.org.uk/pdf/scripture/15-32_110.pdf.

Salgues, B. Society 5.0 Industry of the Future, Technologies, Methods and Tools. London: London: ISTE Ltd., 2018.

Serpa, S., and C. Ferreira. "Society 5.0 and Social Development: Contributions to a

Discussion. Management and Organizational Studies” 5, no. 4 (2018): 26-31.

Shibasaki, Ryosuke, Satoru Hori, Shunji Kawamura, and Shigeyuki Tani. "Integrating Urban

Data with Urban Services.” In Society 5.0: A People-Centric Super-Smart Society, 67-84.

Bunkyo-ku, Tokyo: Springer Open, 2018.

Sider, R. Evangelicals and Development: Towards a Theology of Social Shange,

Contemporary Issues in Social Ethics. 2nd ed. Fitzroy Falls, NSW, Australia: The

Paternoster Press, 1981.

Simon, John C., and Stella.Y.E.Pattipeilohy. Pembangunan Ekonomi Gereja: Refleksi Atas

Praksis Teologi Ekonomi GPIB. PT Kanisius, n.d.

https://books.google.co.id/books?id=z5\%5C_6DwAAQBAJ.

Smit, D.J. "Challenges for Reformed Churches in Africa: A Contemporary Narrative'." International Journal for the Study of the Christian Church 8, no. 4 (2008).

Spaulding, Hendry W., and Hendry W. Spaulding. "Trinitarian Identity of the Church's True Foundation.” In The Essential Church: A Wesleyan Ecclesiologi, 41-43. Kansas City: Beacon Hill, 2014.

Stanmaugh, J., and D Balch. The Social World of the First Christians. Great Britain: Anchor Press, 1986.

Van Der Walt, B.J. Anatomy of Reformation. Potchefstroom: Potchefstroom University for CHE, 1991. 
Warren, R. The Purpose Driven Church: Every Church Is Big in God's Eyes. Michigan: Zondervan Press, 1995.

Winter, Bruce. Seek the Welfare of the City: Christians as Benefactors and Citizens. FirstCentury Christians in the Graeco-Roman World. Grand Rapids: Eerdmans, 1994.

"Menghadapi Era Society 5.0, Perguruan Tinggi Harus Ambil Peran - Website LLDIKTI Wilayah V." Accessed June 22, 2021.

https://lldikti5.kemdikbud.go.id/home/detailpost/menghadapi-era-society-50-perguruantinggi-harus-ambil-peran. 